\title{
A Korean Family with Cholesterol Ester Transfer Pro- tein Deficiency
}

\author{
Seo Young Youn', Ik Soon Shin', Yong Hee Hong ${ }^{2}$ and Dong Hwan Lee ${ }^{1 *}$ \\ 'Department of Pediatrics, College of Medicine, Soonchunhyang University, Seoul, Korea \\ ${ }^{2}$ Department of Pediatrics, Seoul Seong Ae Hospital, Seoul, Korea
}

\begin{abstract}
A 32-year-old female patient and her sister show high levels of high density lipoprotein $(\mathrm{HDL})$ cholesterol in regular health checkups, since female patient was 11 years old. The patient's serum total cholesterol was $285 \mathrm{mg} / \mathrm{dL}$ and HDL cholesterol was $113 \mathrm{mg} / \mathrm{dL}$. Her sister's total cholesterol was $240 \mathrm{mg} / \mathrm{dL}$ and the HDL cholesterol measured to be $90 \mathrm{mg} / \mathrm{dL}$. Lipoprotein pattern and cholesteryl ester transfer activity gene analysis were examined in these patients. We found c.1321+1G>A (IVS14+ $1 \mathrm{G} / \mathrm{A}$ ) hetero mutation in cholesteryl ester transfer protein (CETP) genes. Generally, CETP mediates transfer and exchange of triglycerides and cholesteryl ester between plasma lipoproteins. Also we investigated a key role of HDL-CE and Apo A-1 metabolism. Patients with low levels of CETP have increased serum HDL levels. We hereby report two Korean cases of CETP deficiency in a family. Brief literature review ensues with the cases.
\end{abstract}

Key Words: Cholesteryl ester transfer protein, High density lipoprotein, Hypercholesterolemia

\section{Introduction}

High density lipoprotein (HDL) extracts cholesterol from cells and transports the excessive cholesterol of atherosclerotic lesions. Therefore the serum HDL level is inversely proportional to atherosclerotic cardiovascular diseases. ${ }^{1,2)}$ It has been reported that $1 \mathrm{mg} / \mathrm{dL}$ increase of the serum $\mathrm{HDL}$ can reduce the risk of atherosclerotic cardiovascular diseases by 2-3\%. ${ }^{3,4)}$ The plasma cholesterol ester transfer protein (CETP) mediates transporting as well as exchanging of cholesterol ester and triglyceride among the plasma lipoprotein, and plays an important role for metabolism of HDL-CE and apo A-1. ${ }^{\text {) }}$

Since Kurasaka et al. and Koizumi et al. had reported on CETP gene defect in 1985, CETP gene defect is known as the most common and important cause of HALP (Hyperalphalipoproteinemia) in Japanese population. HALP has been reported as being inherited as an autosomal dominant trait. ${ }^{5-8)}$ Since the CETP gene splicing defect was found in the Japanese pedigree for the first time c.1321+1G>A (IVS14+1G>A), CETP deficiency shows very high prevalence in the Japanese pedigree as shown from a study performed in the Japanese population that had reported CETP deficiency and nucleotide pleomorphism which were caused by mutation of D442G at the same site. $27 \%$ of population in Omagari region of Japan had shown c.1321+1G>A (IVS14+1G>A). Congenital CETP deficiency raises the blood HDL level and reduces the content of cholesterol ester in Very Low Density Lipoprotein (VLDL), intermediate density lipoprotein and chylomicron, consequently resulting in formation of a lipid

Received: 3 June 2012, Revised: 20 June 2012, Accepted: 21 June 2012, Published: 30 June 3012

*Corresponding author: Dong Hwan Lee

Department of Pediatrics, College of Medicine, Soonchunhyang University, 22, Deasagwan-gil, Yongsan-gu, Seoul 140-743, Korea

Tel: +82-2-709-9114, Fax: +82-2-709-9135, E-mail: Idh@schmc.ac.kr

(c) This is an open-access article distributed under the terms of the Creative Commons Attribution Non-Commercial License (http://creativecommons.org/licenses/by-nc/3.0/) which permits unrestricted non-commercial use, distribution, and reproduction in any medium, provided the original work is properly cited.

(c) Copyright 2012 by the Korean Society of Medical Genetics 
profile with low likelihood of atherosclerosis in the human body

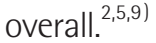

The author, hereby, makes an empirical report on diagnosing cases with CETP deficiency, by using the chromosome gene test in Korean sisters whose HDL were measured at high levels from a periodic health check up, together with report on the literature reviews.

\section{Case Report}

\section{Case 1}

- Patient:32 years old, female

- Chief complaint: Elevation of the serum HDL level accidentally found from regular health check up

- Pasthistory: No specific history

- Family history: No specific history

- Present illness: The patient has precise examination as she found her serum HDL level was elevated from the results of annual health check up since 11 years old

- Physical examination: BP was 110/70 mmHg, body temperature $36.8^{\circ} \mathrm{C}$, pulse rate 70 per min, respiration 20 per min, and there was no specific findings in the medical examination on the skin and head/neck. In terms of thorax, the lung sound was clear, heart beat was regular. There was no palpable lumps and no enlargement of liver and spleen. Also there were no specific findingsin neurological examination.

- Laboratory findings: The results of peripheral blood test performed: WBC was $11,100 / \mu \mathrm{L}$, hemoglobin $12.0 \mathrm{~g} / \mathrm{dL}$, hematocrit 35.3\% and platelet 299,000/ $\mu \mathrm{L}$. The biochemical assay results showed AST $19 \mathrm{IU} / \mathrm{L}$, ALT $14 \mathrm{IU} / \mathrm{L}$, BUN $8.1 \mathrm{mg} / \mathrm{dL}$, Creatinine $0.7 \mathrm{mg} / \mathrm{dL}$, Protein $7.5 \mathrm{~g} / \mathrm{dL}$, Albumin $4.7 \mathrm{~g} / \mathrm{dL}$, Total bilirubin $0.9 \mathrm{mg} / \mathrm{dL}$ and Inorganic phosphate $4.1 \mathrm{mg} / \mathrm{dL}$ The test results on overnight fasting lipid profiles included: Total cholesterol 285 mg/dL (Normal range 130-220), Triglyceride $73 \mathrm{mg} / \mathrm{dL}$ (Normal range 0-200), HDL-cholesterol $113 \mathrm{mg} /$ dL (Normal range 49-74) and the electrolytes were Na 138 $\mathrm{mmol} / \mathrm{L}, \mathrm{K} 4.8 \mathrm{mmol} / \mathrm{L}$ and $\mathrm{Cl} 103 \mathrm{mmol} / \mathrm{L}$. There was no abnormal results from the urine test. The blood lipoprotein electrophoresis test also had no abnormality in its results. But from the CETP gene test, c.1321+1G>A (IVS14+1G/A) hetero mutation was identified.

- Treatments and Prognosis: Based on abnormal findings from the blood test, a gene analysis was performed and diagnosis was made. The patient is currently under no specific treatment.

\section{Case 2}

- Patient:28years old, female

- Chief complaint: Elevation of the serum HDL level accidentally found from regular health check up

- Pasthistory: No specific history

- Family history: All family members including 1 brother and 2 sisters had shown the elevation of the serum HDL level

- Present illness: The patient had visited our hospital to have a precise examination as she found her blood HDL level was elevated from the results of annual health check up since 9 years old

- Physical examination: Height was $162 \mathrm{~cm}$, weight was $52 \mathrm{~kg}$, and body mass index (BMI) was $19.8 \mathrm{~kg} / \mathrm{m}^{2}$. BP was $120 / 70$ $\mathrm{mmHg}$, body temperature $36.8^{\circ} \mathrm{C}$, pulse rate 70 per min, respiration 20 per min, and there was no specific findings in the medical examination on the skin and head/neck. In terms of thorax, the lung sound was clear, heart beat was regular. There were no palpable lumps and no enlargement of liver and spleen found from abdominal examination. Also there was no specific finding in neurological examination.

- Laboratory findings:The results of peripheral blood test performed at the time of visit: WBC was $5,400 / \mu \mathrm{L}$, hemoglobin $12.9 \mathrm{~g} / \mathrm{dL}$, hematocrit 40.3\% and platelet 295,000/ $\mathrm{LL}$. The biochemical assay results showed AST $13 \mathrm{IU} / \mathrm{L}$, ALT $12 \mathrm{IU} / \mathrm{L}$, BUN $12.0 \mathrm{mg} / \mathrm{dL}$, Creatinine $0.7 \mathrm{mg} / \mathrm{dL}$, Protein $6.4 \mathrm{~g} / \mathrm{dL}$, Albumin $4.0 \mathrm{~g} / \mathrm{dL}$, Total bilirubin $0.7 \mathrm{mg} / \mathrm{dL}$ and Inorganic phosphate $3.5 \mathrm{mg} / \mathrm{dL}$ while the test results on the blood lipid included: Total cholesterol 240 $\mathrm{mg} / \mathrm{dL}$ (Normal range 130-220), Triglyceride $70 \mathrm{mg} / \mathrm{dL}$ (Normal range 0-200), HDL-cholesterol 90 mg/dL (Normal range 4974) and the electrolytes were $\mathrm{Na} 139 \mathrm{mmol} / \mathrm{L}, \mathrm{K} 4.0 \mathrm{mmol} / \mathrm{L}$ and $\mathrm{Cl} 103 \mathrm{mmol} / \mathrm{L}$ There were no abnormal results from the urine test. The results of lipoprotein test had shown Apolipoprotein A as $204.06 \mathrm{mg} / \mathrm{dL}$ (Normal range 79-169), Apolipoprotein B was $104.94 \mathrm{mg} / \mathrm{dL}$ (Normal range 46-174) and B-Lipoprotein was 446 $\mathrm{mg} / \mathrm{dL}$ (Normal range 200-680) in its results. The CETP gene test, c. 1321+1G>A (IVS14+1G>A) hetero mutation wasidentified.

- Treatments and Prognosis: Based on abnormal findings from the blood test, a gene analysis was performed and diagnosis was made. The patient is currently under no specific treatment.

\section{Discussion}

The serum lipoprotein is a complex as a carrier of lipid between the body fluids and tissues, and it is indispensable for absorptions of cholesterol and lipophilic vitamins. It transports triglyceride, 
cholesterol and lipophilic vitamins between the liver and the peripheral tissues as well as inversely transports cholesterol from the peripheral tissues to the liver. The serum HDL is synthesized at the small intestines and the liver inside human body, and lipids and phospholipids degraded at peripheral parts are transported as HDL. ${ }^{9,10)}$

The existence of highly concentrated HDL in the blood has been widely known as one of independent factors to prevent atherosclerotic coronary diseases from most studies. 2004 Revised Version of the Adult treatment Panel III had considered that when the serum HDL level is $\geq 60 \mathrm{mg} / \mathrm{dL}$, it becomes an advantageous factor for prevention of atherosclerotic coronary diseases. ${ }^{4,11}$

CETP, which has been known as an important factor with effects on the serum HDL level, consists of 476 amino acids and 4 of $\mathrm{N}-\mathrm{I}$ inked glycosylation as hydrophobic glycoprotein. ${ }^{11)}$ In case of the human CETP gene, it is composed of 16 exons, and is $25 \mathrm{kbp}$ in size. It is located at the chromosome $16 q 21$ adjacent to the coordinate of lecithin cholesterol acyltransferase gene (16q22). ${ }^{12)}$ Ten mutation of the CETP gene has been demonstrated as cause of HALP. The splicing defect of intron 14 is the most common mutation. And single nucleotide polymorphisms such as C-631A, C-629A, Taq1B, A373P, 1405V and D4442G, R4510 are well known. ${ }^{5,13,14)}$

It also plays an important role for CETP-induced HDL metabolism in primary or secondary hyperlipidemia as well as post-meal lipidemia. As cholesterol ester is carried in the form of VLDL or chylomicron, the transport of cholesterol ester in HDL is reduced and the cholesterol ester is pulled out of HDL particles reducing its size and presenting the serum HDL level being dropped. Based on the above results, it can also cause excessive amounts of cholesterol ester in the potential atherosclerotic substances such as VLDL or chylomicron. ${ }^{9}{ }^{\text {15) }}$

Meanwhile, CETP gene deficiency induces dropping down of the serum CETP level which is led to the elevation of the serum CETP level. The relevance between CETP gene polymorphism, the serum lipoprotein concentrations and cardiovascular diseases can be presented in diversity depending on different races and frequency of gene polymorphism. ${ }^{9,16)}$

Some authors said CETP gene deficiency is associated with long life as it increases the HDL level and then reduces atherosclerotic coronary diseases. ${ }^{17-19)}$ However, others had reported that CETP deficiency increases atherosclerotic coronary diseases in spite of HDL's elevation, due to retrograde cholesterol disorder. ${ }^{6,10)}$ Although CETP deficiency generates anti-artherogenic lipoprotein profile, the benefits of CETP deficiency still remain as controversial so far. $12,14,20,211)$
In the cases presented by the authors, it was possible to diagnose CETP gene polymorphism by performing the chromosome gene analysis in two sisters from the same family who had visited our hospital due to persistent elevation of the blood HDL level from periodic health check-upssince 9 and 11 year old.

In summary, we make an empirical report on identification of gene mutation from the same site in Korean population by performing CETP gene analysis and the serum cholesterol distribution characteristics as shown in two sisters from one family who had shown persistently high HDL level from periodic health check-upssince 9 and 11 years old.

\section{References}

1. Alan R. The Effects of Cholesterol Ester Transfer Protein Inhibition on Cholesterol Efflux. Am J Cardiol 2009;104:39-45.

2. Brown ML, Inazu A, Hesler CB, Agellon LB, Mann C, Whitlock ME, et al. Molecular basis of lipid transfer protein deficiency in a family with increased high-density lipoproteins. Nature 1989;342:448-51.

3. Barkowski RS, Frishman WH. HDL metabolism and CETP inhibition Cardiol rev 2008;16:154-62.

4. Barter P, Gotto AM, LaRosa JC, Maroni J, Szarek M, Grundy SM, et al. HDL Cholesterol, Very Low Levels of LDL Cholesterol, and Cardiovascular Events. N Engl J Med 2007;357:1301-10.

5. Nagano M, Yamashita S, Hirano K, Takano M, Maruyama T, Ishihara M, et al. Molecular mechanisms of cholesteryl ester transfer protein deficiency in Japan. J Atheroscler Thromb 2004;11:110-21.

6. Nagano $M$, Yamashita $S$, Hirano $K$, Ito M, Maruyama $T$, Ishihara $M$, et al. Two novel missense mutations in the CETP gene in Japanese hyperalphalipoproteinemic subjects: high-throughput assay by Invader assay. J Lipid Res 2002;43:1011-8.

7. Kurasawa T, Yokoyama S, Miyake Y, Yamamura T, Yamamoto A. Rate of Cholesteryl Ester Transfer between high and low density lipoproteins in human serum and case with decreased transfer rate in association with hyperalphalipoproteinemia. J Biochem, 1985;98:1499-508.

8. Koizumi J, Mabuchi H, Yoshimura A, Michishita I, Takeda M, Itoh H, et al. Deficiency of serum cholesteryl-ester transfer activity in patients with familial hyperalphalipoproteinemia. Atherosclerosis 1985;58:17586.

9. Ai M, Tanaka A, Shimokado K, Ohtani R, Inazu A, Kobayashi J, et al. A deficiency of cholesteryl ester transfer protein whose serum remnantlike particle-triglyceride significantly increased, but serum remnantlike particle-cholesterol did not after an oral fat load. Ann Clin Biochem 2009:46:457-63.

10. H. Bryan Brewer. Increasing HDL Cholesterol Levels. N Eng J Med 2004; 350:1491-4. 
11. Grundy SM, Cleeman JI, Merz CN, Brewer HB, Clark LT, Hunninghake $\mathrm{DB}$, et al. Implications of recent clinical trials for the National Cholesterol Education Program Adult Treatment Panel III guidelines. J Am Coll Cardiol 2004:44:720-32.

12. Teh EM, Dolphin PJ, Breckenridge WC, Tan MH. Human plasma CETP deficiency: identification of a novel mutation in exon 9 of the CETP gene in a Caucasian subject from North America. J Lipid Res 1998;39: 442-56.

13. Hirano K, Yamashita S, Nakajima N, Arai T, Maruyama T, Yoshida $Y$, et al. Marked Hyperalphalipoproteinemia Caused by CETP Gene Mutation Is Not Associated With Longevity. Arterioscler Thromb Vasc Biol 1997;17:1053-9.

14. Moriyama $Y$, Okamura $T$, Inazu A, Doi $M$, Iso $H_{1}$ Mouri $Y$, et al. A low prevalence of coronary heart disease among subjects with increased high-density lipoprotein cholesterol levels, including those with plasma cholesteryl ester transfer protein deficiency. Prev Med 1998;27:65967.

15. Bisgaier CL, Siebenkas MV, Brown ML, Inazu A, Koizumi J, Mabuchi H, et al. Familial cholesteryl ester transfer protein deficiency is associated with triglyceride-rich low density lipoproteins containing cholesteryl esters of probable intracellular origin. J Lipid Res 1991; 32:21-33.

16. Barter P, Rye KA. The Effects of Cholester Cholesteryl ester transfer protein inhibition to reduce cardiovascular risk: where are we now.
Trends Pharmacol Sci 2011;32:694-9.

17. Curb JD, Abbott RD, Rodriguez BL, Masaki K, Chen R, Sharp DS, et al. A prospective study of HDL-C and cholesteryl ester transfer protein gene mutations and the risk of coronary heart disease in the elderly. J Lipid Res 2004;45:948-53.

18. Boekholdt SM, Kuivenhoven JA, Wareham NJ, Peters RJ, Jukema JW, Luben $R$, et al. Plasma Levels of Cholesteryl Ester Transfer Protein and the Risk of Future Coronary Artery Disease in Apparently Healthy Men and Women The Prospective EPIC (European Prospective Investigation into Cancer and nutrition)-Norfolk Population Study. Circulation 2004;110:1418-23.

19. Zhong S, Sharp DS, Grove JS, Bruce C, Yano K, Curb JD, et al. Increased Coronary Heart Disease in Japanese-American Men with Mutation in the Cholesteryl Ester Transfer Protein Gene Despite Increased HDL Levels. J Clin Invest 1996;97:2917-23.

20. Nagano M, Nakamura M, Kobayashi N, Kamata J, Hiramori K. Effort Angina in a Middle-Aged Woman With Abnormally High Levels of Serum High-Density Lipoprotein Cholesterol- A Case of Cholesteryl-Ester Transfer Protein Deficiency. Circ J 2005;69:609-12.

21. Gordon DJ, Probstfield JL, Garrison RJ, Neaton JD, Castelli WP, Knoke JD, et al. High-density lipoprotein cholesterol and cardiovascular disease: four prospective American studies. Circulation 1989;79:8-15. 